\title{
Content of Heavy Metals in Reclaimed Soil Material and Hard Coal ash 15 Years After the Experiment
}

\author{
Marzena Gibczyńska1 ${ }^{*}$, Tomasz Tomaszewicz², Sławomir Stankowski ${ }^{3}$ \\ Justyna Chudecka², Renata Gamrat ${ }^{2}$ \\ 1 Department of Bioengineering, West Pomeranian University of Technology in Szczecin, Słowackiego 17, \\ 71-434 Szczecin, Poland \\ 2 Department of Environmental Management, West Pomeranian University of Technology in Szczecin, \\ Słowackiego 17, 71-434 Szczecin, Poland \\ 3 Department of Agroengineering, West Pomeranian University of Technology in Szczecin, Papieża Pawła VI 3, \\ 71-459 Szczecin, Poland \\ * Corresponding author's e-mail: marzena.gibczynska@zut.edu.pl
}

\begin{abstract}
The paper the results obtained during hard coal ash reclamation. This model was created by covering the ash surface with the layers consisting of ash, organic by-products and mineral fertilizers. The aim of the studies, undertaken 15 years after the experiment set up, was the assessment of the efficacy of ash waste reclamation on the basis of the overall and solubility analyses of the metal content, including heavy metals, soluble in $1 \mathrm{M} \mathrm{HCl}$. In 2003, on the premises of Dolna Odra Power Station in Nowe Czarnowo $\left(53,20^{\circ} \mathrm{N} ; 14,48^{\circ} \mathrm{E}\right)$ near Gryfino $\left(53,25^{\circ} \mathrm{N}\right.$; $14,48^{\circ} \mathrm{E}$ ) in Poland, a hard coal ash reclamation experiment was conducted. A $40 \mathrm{~cm}$ thick surface layer (fertile), termed upperlay, composed of the mixture of various materials was applied to ash substrate. One part was fertilized with mineral fertilizers NPK-60-70-70, the other was left unfertilized. After 15 years, in the autumn of 2018, the samples of upperlays $(0-40 \mathrm{~cm})$ and underlays $(40-60 \mathrm{~cm})$ were collected from plots overgrown with grass. Fifteen years after the experiment, none of the underlays or upperlays showed an excess of threshold values, as specified in the current Regulation of the Minister of the Environment of 2016. The particularly favourable effect was identified with respect to the application of fermented municipal sewage sludge and GWDA compost which were factors resulting in a decrease of the upperlay content of cadmium, zinc, copper and lead in the form available for plants. The characteristics of upperlays with respect to metal content indicate the conditions favourable to plant cultivation on the reclaimed area. The recorded results on the change of the overall and bioavailable content of metals in upperlays and underlays justify the continuation of the undertaken reclamation experiment.
\end{abstract}

Keywords: metals, upperlay, underlay, hard coal ash, fermented municipal sewage sludge

\section{INTRODUCTION}

According to the Regulation of the Minister of Climate on waste catalog, combustion byproducts (CBP) coded 100101 , i.e., ash produced by the power sector and described therein as slag, bottom ash and boiler ash, are not hazardous waste and therefore can be subject to reclamation treatment and subsequently used in agriculture [Journal of Laws of 2020, item 10].

In addition to high content of soil deacidification compounds, ash contains a number of metals, including heavy metals, showing toxic effects. Heavy metals include: lead, cadmium, nickel, copper, and zinc. The excessive amount of heavy metals in soil causes degradation of its chemical properties. Heavy metals are one of the important factors that are hazardous to organisms, since when introduced to the environment - they undergo biological accumulation. This is particularly the case with metals such as cadmium, zinc, mercury, copper and lead [Ibragimow et al. 2010]. Due to the slow rate of displacement into soil, metals accumulate in the surface layer of soil. The mobility 
and bioavailability of metals to a large extent depend on soil properties, mostly its texture, $\mathrm{pH}$ and organic matter content [www.gios.gov.pl]. The Regulation of the Minister of the Environment of 1 September 2016 on the method of conducting the assessment of land surface contamination specifies the permissible contamination levels of soil or ground with heavy metals and provides soil and ground classification to particular land use [Journal of Laws of 2016, item 1395].

The ecological risk due to the environmental pollution with heavy metals is not specifically related to the total content of metals. The assessment of the risk to the environment is conducted using, among others, the tests on the soluble forms of metals. The analysis of the current or potential heavy metal solubility informs on the ecological threat due to the possibility of these elements being included in the biogeochemical circulation. The effect of hard coal ash on soil and plant properties is well researched, though there is definitely less information on the changes characteristic for ashes following their introduction to soil, for example during reclamation practices.

The present paper present the results obtained during the hard coal ash reclamation. This model was created by covering the ash surface with layers consisting of ash, organic by-products and mineral fertilizers. The aim of the studies, undertaken 15 years after the experiment set up, was the assessment of the efficacy of ash waste reclamation on the basis of the overall and solubility analyses of the metal content, including heavy metals, soluble in $1 \mathrm{M} \mathrm{HCl}$.

\section{MATERIALS AND METHODS}

\section{Experiment set up}

In 2003, on the premises of Dolna Odra Power Station in Nowe Czarnowo $\left(53,20^{\circ} \mathrm{N}\right.$; $\left.14,48^{\circ} \mathrm{E}\right)$ near Gryfino $\left(53,25^{\circ} \mathrm{N} ; 14,48^{\circ} \mathrm{E}\right)$ in Poland, a hard coal ash reclamation experiment was conducted. A $40 \mathrm{~cm}$ thick surface layer (fertile), termed upperlay, composed of the mixture of various materials was applied to ash substrate. The characteristics of five upperlays were presented in Table 1. Vegetation in the form of grass mixture: Festuca rubra (45\%), Lolium perenne (35\%) and Poa pratensis $(25 \%)$ was introduced to plots of an area $100 \mathrm{~m}^{2}$ each. Until 2006, the parcels were mown, fertilized and subjected to pratotechnical treatment. The layer of ash, termed underlay, below each of the upperlays was divided into two parts. One part was fertilized with the NPK-60-70-70 mineral fertilizers, the other was left unfertilized. After 15 years, in the autumn of 2018 , the samples of upperlays $(0-40 \mathrm{~cm})$ and underlays $(40-60 \mathrm{~cm})$ were collected from plots overgrown with grass. The samples taken from upperlays are anthropogenic soils formed by covering the ash with the fertile surface layer. The resulting

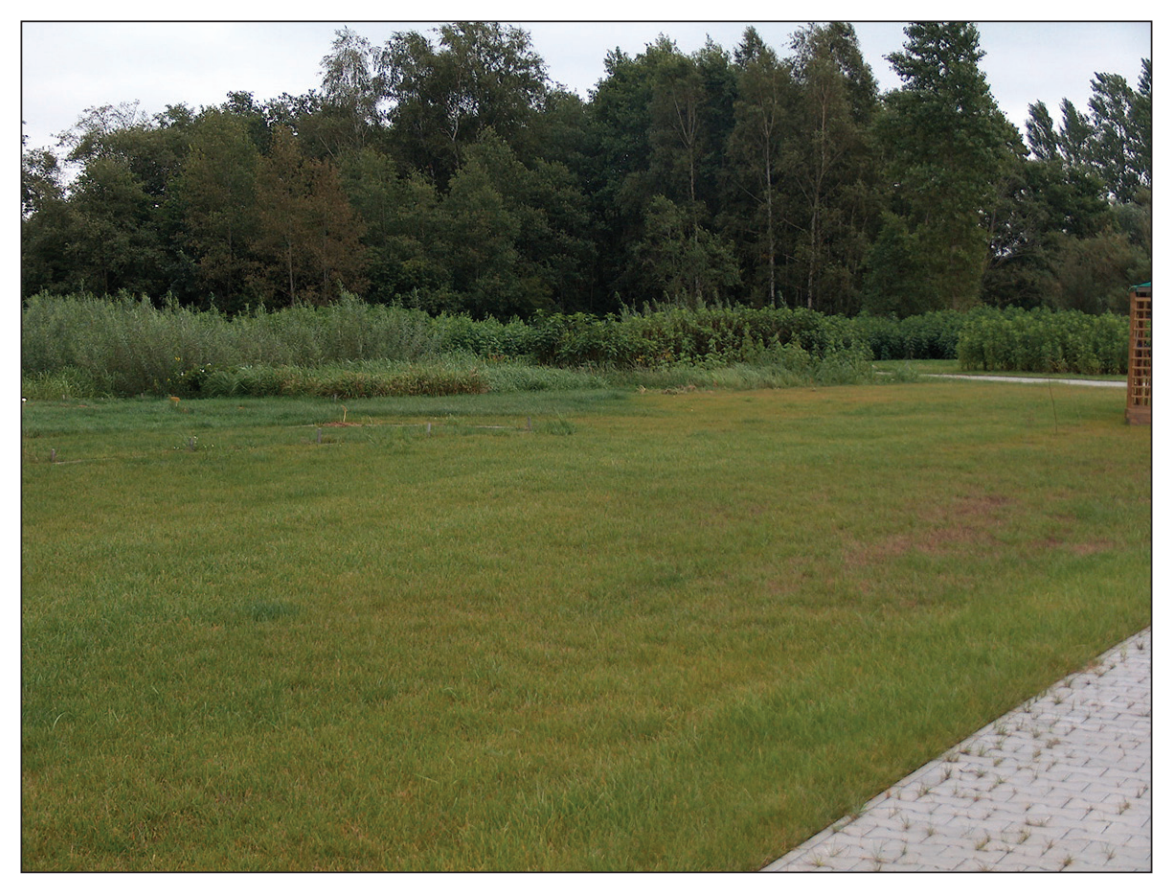

Phot. 1. Photograph of the area 15 years after reclamation 
Table 1. Fertilization scheme

\begin{tabular}{|c|c|c|c|c|c|}
\hline \multirow[b]{3}{*}{ Upperlay } & \multicolumn{5}{|c|}{ Upperlay and underlay number } \\
\hline & I & II & III & IV & V \\
\hline & $\begin{array}{l}\text { Low peat } \\
\quad+\text { ash. } \\
\text { Proportion } 1: 3\end{array}$ & $\begin{array}{c}\text { Coniferous } \\
\text { wood bark + } \\
\text { loose sand } \\
\text { + GWDA } \\
\text { compost, ash. } \\
\text { Proportion } \\
1: 1: 2: 4\end{array}$ & $\begin{array}{c}\text { Loose sand + GWDA } \\
\text { compost + fermented } \\
\text { municipal sewage } \\
\text { sludge (dry weight: } \\
70 \% \text { sludge, } 15 \% \\
\text { urban green areas } \\
\text { waste, } 15 \% \text { straw). } \\
\text { Proportion } 1: 1: 2\end{array}$ & $\begin{array}{c}\text { Loose sand + ash + } \\
\text { GWDA compost }+ \\
\text { fermented municipal } \\
\text { sewage sludge (dry } \\
\text { weight: } 70 \% \text { sludge, } \\
30 \% \text { urban green areas } \\
\text { waste). Proportion } \\
0.5: 0.5: 1: 2\end{array}$ & $\begin{array}{c}\text { Loose sand + coniferous } \\
\text { wood bark + GWDA } \\
\text { compost + fermented } \\
\text { municipal sewage sludge } \\
\text { (dry weight: } 70 \% \text { sludge, } \\
30 \% \text { straw). Proportion } \\
1: 1: 2: 4\end{array}$ \\
\hline $\begin{array}{l}\text { Unfertilized } \\
\text { underlay }\end{array}$ & Ash & Ash & Ash & Ash & Ash \\
\hline $\begin{array}{l}\text { Fertilized } \\
\text { underlay }\end{array}$ & $\begin{array}{l}\text { Ash + NPK } \\
(60-70-70)\end{array}$ & $\begin{array}{l}\text { Ash + NPK } \\
(60-70-70)\end{array}$ & $\begin{array}{l}\text { Ash + NPK } \\
(60-70-70)\end{array}$ & $\begin{array}{l}\text { Ash + NPK } \\
(60-70-70)\end{array}$ & $\begin{array}{l}\text { Ash + NPK } \\
(60-70-70)\end{array}$ \\
\hline
\end{tabular}

anthropogenic soils are to be defined as Humic industrizems (AIpr) of a profile sequence: Aan2Can [Kabała et al. 2019].

\section{Chemical analyses}

The collected samples were dried and ground in accordance with the requirements specified in the ISO 18400-102:2017 standard. The soil $\mathrm{pH}$ was identified potentiometric using an Orion Star A $211 \mathrm{pH}$-meter, in accordance with ISO 10390:2005. In order to determine the total metal content, the soil samples were wet mineralized in the mixture of nitric $(\mathrm{V})$ and chloric(VII) acid in a 1:1 ratio, in the proportion of $1 \mathrm{~g}$ of soil and $10 \mathrm{dm}^{3}$ of acid solution. The contents of the potentially available forms of metals were determined following extraction with a $1 \mathrm{M} \mathrm{HCl}$ solution, in the soil to solution ratio 1:10 [Kabała and Karczewska 2019]. Extraction of $1 \mathrm{M}$ with the $\mathrm{HCl}$ solution is widely used in agricultural research for determining the bioavailability of metals, as well as for the assessment of the environmental contamination status. In the obtained extracts, the metal content was determined using an Atomic Absorption Spectrometer Apparatus (Thermo Fisher Scientific iCE 3000 Series).

\section{Statistical analysis}

The results were statistically developed using analysis of variance in one-factor random blocks design. Confidence half-intervals were calculated with Tukey's multiple test, the adopted significance level was $p=0.05$ [Hill et al. 2006]. The statistical analysis of the results was conducted with the Statistica 10.0 software.

\section{RESULTS AND DISCUSSION}

According to the standards applicable to soils, upperlay layers I and II $\left(\mathrm{pH}_{\mathrm{KCl}}=7.4\right.$ and 7.6) showed acidic $\mathrm{pH}$. Application of the acidifying agent in the form of municipal sewage sludge and GWDA compost to the remaining three upperlays resulted in the $\mathrm{pH}$ level $\mathrm{pH}_{\mathrm{KCl}} 6.66-6.99$. The analysed underlays are to be characterised as alkaline (average $\mathrm{pH}_{\mathrm{KCl}}=8.39$ ) [ISO 10390:2005].

Iron, the most abundant trace element, takes part in a number of life processes of plants such as: respiration, photosynthesis, nitrate decomposition and free nitrogen fixation. The amount of iron in hard coal ash varies from 5 to $22 \%$ [Parzentny and Róg 2017]. The availability of iron to plants is more accurately determined by the content of soluble iron in a $1 \mathrm{M} \mathrm{HCl}$ solution than by its general form. The amount of soluble iron in upperlays of the reclamation model ranged from 2 to $3 \mathrm{~g} \mathrm{~kg}^{-1}$, and in underlays $2 \mathrm{~g} \mathrm{~kg}^{-1}$ (Table 2 and 3 ). Considering the layers of upperlays and underlays as soil, the content of soluble iron in $1 \mathrm{M} \mathrm{HCl}$ is moderate. Depending on the soil class, the values $700-3800 \mathrm{mg} \mathrm{kg}^{-1}$ of soil are adopted as mean values [DIN-R-04021:1994; Lipiński 2013].

The approach adopted more recently assumes that the new threshold values for $1 \mathrm{M} \mathrm{HCl}$ should take into account variable plant susceptibility to microelement deficiency. The old values considered only the selected features of soil, rather than the plant requirements. Additionally, the single-level values have been developed and, as opposed to the three-level values which defined the low/mean/high content, they provide only the determination of low microelement content in soil i.e., the values below which fertilization is indicated. The new values indicating the need 
Table 2. Metal content in upperlays $\left[\mathrm{mg} \mathrm{kg}^{-1}\right]$

\begin{tabular}{|c|c|c|c|c|c|}
\hline \multirow{2}{*}{ Metal } & \multicolumn{5}{|c|}{ Upperlay number } \\
\hline & I & II & III & IV & $\mathrm{V}$ \\
\hline \multicolumn{6}{|c|}{ Content of soluble forms of metals in $1 \mathrm{M} \mathrm{HCl}$} \\
\hline Iron & $2746^{\mathrm{a}} \pm 624$ & $2128^{a} \pm 217$ & $2362^{\mathrm{a}} \pm 228$ & $3013^{a} \pm 205$ & $1935^{\mathrm{a}} \pm 88$ \\
\hline Manganese & $177^{a} \pm 26$ & $142^{\mathrm{a}} \pm 4.1$ & $140^{\mathrm{a}} \pm 7.1$ & $175^{\mathrm{a}} \pm 5.7$ & $151^{\mathrm{a}} \pm 4.0$ \\
\hline Cadmium & $0.196^{\mathrm{a}} \pm 0.025$ & $0.211^{\mathrm{a}} \pm 0.024$ & $0.121^{b} \pm 0.022$ & $0.121^{\mathrm{b}} \pm 0.014$ & $0.128^{b} \pm 0.014$ \\
\hline Zinc & $82.6^{a} \pm 5.9$ & $77.5^{\mathrm{a}} \pm 3.2$ & $26.6^{b} \pm 3.6$ & $77.0^{\mathrm{b}} \pm 2.3$ & $43.4^{b} \pm 6.3$ \\
\hline Copper & $20.3^{\mathrm{a}} \pm 2.1$ & $20.0^{\mathrm{a}} \pm 1.4$ & $12.1^{\mathrm{b}} \pm 1.2$ & $16.6^{\mathrm{ab}} \pm 1.0$ & $13.3^{\mathrm{b}} \pm 1.0$ \\
\hline Lead & $11.0^{\mathrm{a}} \pm 1.9$ & $14.0^{\mathrm{a}} \pm 1.9$ & $4.8^{\mathrm{b}} \pm 1.4$ & $3.0^{\mathrm{b}} \pm 1.2$ & $3.4^{\mathrm{b}} \pm 1.3$ \\
\hline Nickel & $2.77^{\mathrm{b}} \pm 0.74$ & $3.13^{b} \pm 1.00$ & $5.44^{a} \pm 0.54$ & $5.81^{a} \pm 0.64$ & $3.04^{b} \pm 0.11$ \\
\hline Cobalt & $2.45^{a} \pm 0.32$ & $2.48^{a} \pm 0.23$ & $2.49^{a} \pm 0.103$ & $2.64^{\mathrm{a}} \pm 0.35$ & $2.32^{\mathrm{a}} \pm 0.20$ \\
\hline \multicolumn{6}{|c|}{ Overall content of heavy metals } \\
\hline Zinc & $99.2^{\mathrm{a}} \pm 6.0$ & $101.0^{\mathrm{a}} \pm 9.2$ & $97.1^{\mathrm{a}} \pm 5.5$ & $93.3^{\mathrm{a}} \pm 4.3$ & $97.2^{\mathrm{a}} \pm 7.8$ \\
\hline Copper & $37.6^{\mathrm{a}} \pm 4.3$ & $46.6^{\mathrm{a}} \pm 4.1$ & $34.4^{\mathrm{b}} \pm 2.8$ & $43.5^{\mathrm{ab}} \pm 3.0$ & $13.3^{\mathrm{b}} \pm 1.0$ \\
\hline Lead & $17.1^{\mathrm{a}} \pm 1.7$ & $20.5^{\mathrm{a}} \pm 2.6$ & $20.7^{\mathrm{a}} \pm 2.8$ & $20.7^{\mathrm{a}} \pm 1.4$ & $19.6^{\mathrm{a}} \pm 1.1$ \\
\hline Nickel & $24.3^{b} \pm 4.5$ & $29.2^{\mathrm{ab}} \pm 4.30$ & $37.3^{\mathrm{ab}} \pm 4.3$ & $49.0^{\mathrm{a}} \pm 3.8$ & $29.1^{\mathrm{ab}} \pm 3.8$ \\
\hline Cobalt & $7.75^{\mathrm{b}} \pm 1.61$ & $9.52^{\mathrm{a}} \pm 1.68$ & $11.32^{\mathrm{a}} \pm 1.53$ & $14.78^{\mathrm{a}} \pm 1.17$ & $9.21^{b} \pm 1.33$ \\
\hline
\end{tabular}

to fertilize the soil, with reference to soluble iron, are 550-1200 $\mathrm{Fe} \mathrm{mg} \mathrm{kg}{ }^{-1}$ [Korzeniowska et al. 2020]. Given these criteria, there was an indication to fertilize the reclaimed area with iron.

Manganese is an indispensable element for plants which participates in metabolic processes, mainly in photosynthesis and functions as an enzyme, oxidiser and a reducer [Millaleo et al. 2010]. On average, the manganese content in hard coal ash is adopted at $860 \mathrm{mg} \mathrm{kg}^{-1}$ [Antonkiewicz 2007]. However, according to Kabata-Pendias [2011], soils are characterised by a lower content of manganese, ranging from 411 to $550 \mathrm{Mn} \mathrm{mg} \mathrm{kg}^{-1}$. In the upperlays analysed in the present reclamation experiment, the amount of manganese soluble in $1 \mathrm{M} \mathrm{HCl}$ ranged from 140 to $177 \mathrm{Mn} \mathrm{mg} \mathrm{kg}^{-1}$, and in the underlays it was found to be higher to some extent: $166-181 \mathrm{mg} \mathrm{kg}^{-1}$ (Table 2 and 3). In line with the adopted criteria for medium soils of $\mathrm{pH}$ level more than 5.5, the layers of upperlays and underlays were characterised by a moderate amount of soluble manganese [Lipiński 2013]. According to the new criteria presented by Korzeniowska et al [2020] stating that in the soils of pH level 6.6-7.2 the threshold value is $130 \mathrm{Mn} \mathrm{mg} \mathrm{kg}$, there was no indication to apply manganese fertilization to the experimental upperlays and underlays.

There was no differentiation in the content of manganese soluble in $1 \mathrm{M} \mathrm{HCl}$ with respect to the constituents of the given upperlay or underlay (Table 2 and 3 ).

When conducting the assessment of the abundance of metals in upperlays and underlays, their overall content as well as that available for plants, i.e. soluble in $1 \mathrm{M} \mathrm{HCl}$, should be considered. Assimilation of macroelements is determined by a number of factors, mainly the environmental $\mathrm{pH}$. Cadmium is one of the most toxic heavy metal elements in soil environment, due to its strong chemical activity, high mobility, permanent toxicity and no biodegradability, as well as the fact that it is readily absorbed from the soil solution by plant root system [Yu et al. 2017]. In light of the current knowledge, such elements as cadmium and lead do not have any physiological functions [Chaney 2010]. In upperlays III, IV and V, soluble cadmium was found to be less abundant, which most likely resulted from a more acidic $\mathrm{pH}$ of these layers. In underlays, the relationship was found to be inverse (Table 2 and 3). Given the data presented by Ociepa et al. [2013], it can be assumed that soluble cadmium constituted $80 \%$ of the overall amount. The cadmium content in the reclaimed layers ranged from 0.162 to $0.477 \mathrm{mg} \mathrm{kg}^{-1}$ and the values were below the admissible levels for soils as specified in the Regulation of the Minister of the Environment of 1 September 2016 on the method of conducting the assessment of land surface contamination [Journal of Laws of 2016, item 1395].

Zinc is an element indispensable for the processes regulating plant metabolism and its deficient levels in soil can result in a decreased plant yield [Liu et al. 2018]. In all experimental upperlays, there was no differentiation with respect to the overall zinc amount. However, the results on soluble zinc confirm the fact that zinc uptake 
Table 3. Content of soluble forms of metals in underlays $\left[\mathrm{mg} \mathrm{kg}^{-1}\right]$

\begin{tabular}{|c|c|c|c|c|c|}
\hline \multirow{2}{*}{ Metal } & \multicolumn{5}{|c|}{ Underlay number } \\
\hline & 1 & II & III & IV & V \\
\hline Iron & $2021^{b} \pm 97$ & $2389^{a} \pm 79$ & $2382^{a} \pm 111$ & $2321^{a} \pm 85$ & $2394^{a} \pm 87$ \\
\hline Manganese & $170,4^{a} \pm 17.7$ & $167.9^{\mathrm{a}} \pm 18.8$ & $178.8^{a} \pm 15.3$ & $166.8^{\mathrm{a}} \pm 14.9$ & $181.0^{a} \pm 16.9$ \\
\hline Cadmium & $0.176^{b} \pm 0.066$ & $0.130^{\mathrm{b}} \pm 0.048$ & $0.321^{\mathrm{a}} \pm 0.042$ & $0.382^{\mathrm{a}} \pm 0.061$ & $0.293^{\mathrm{a}} \pm 0.049$ \\
\hline Zinc & $18.0^{\mathrm{a}} \pm 0.7$ & $20,8^{a} \pm 0.8$ & $18.9^{\mathrm{a}} \pm 1.3$ & $19.6^{\mathrm{a}} \pm 0.7$ & $20.8^{a} \pm 1.0$ \\
\hline Copper & $18.1^{\mathrm{c}} \pm 1.2$ & $17.6^{\mathrm{c}} \pm 0.8$ & $30.6^{a} \pm 2.0$ & $31.0^{\mathrm{a}} \pm 2.1$ & $24.6^{b} \pm 0.9$ \\
\hline Lead & $5.09^{a} \pm 0.41$ & $5.43^{\mathrm{a}} \pm 0.51$ & $6.06^{\mathrm{a}} \pm 0.31$ & $5.21^{\mathrm{a}} \pm 0.42$ & $4.86^{a} \pm 0.51$ \\
\hline Nickel & $4.00^{\mathrm{a}} \pm 0.34$ & $7.18^{\mathrm{a}} \pm 0.35$ & $2.95^{\mathrm{a}} \pm 0.23$ & $2.95^{\mathrm{a}} \pm 0.22$ & $6.73^{\mathrm{a}} \pm 0.42$ \\
\hline Cobalt & $2.46^{a} \pm 0.19$ & $3.15^{\mathrm{a}} \pm 0.32$ & $2.47^{\mathrm{a}} \pm 0.29$ & $3.19^{\mathrm{a}} \pm 0.46$ & $2.83^{a} \pm 0.16$ \\
\hline Metal & \multicolumn{3}{|c|}{ Unfertilized underlay } & \multicolumn{2}{|c|}{ Fertilized underlay } \\
\hline Iron & \multicolumn{3}{|c|}{$2398^{a} \pm 120$} & \multicolumn{2}{|c|}{$2204^{a} \pm 114$} \\
\hline Manganese & \multicolumn{3}{|c|}{$160.6^{\mathrm{a}} \pm 8.1$} & \multicolumn{2}{|c|}{$180.4^{\mathrm{a}} \pm 8.8$} \\
\hline Cadmium & \multicolumn{3}{|c|}{$0.158^{\mathrm{b}} \pm 0.023$} & \multicolumn{2}{|c|}{$0.362^{\mathrm{a}} \pm 0.032$} \\
\hline Zinc & \multicolumn{3}{|c|}{$20.6^{a} \pm 0.7$} & \multicolumn{2}{|c|}{$19.6^{a} \pm 0,8$} \\
\hline Copper & \multicolumn{3}{|c|}{$23.5^{\mathrm{a}} \pm 1.9$} & \multicolumn{2}{|c|}{$25.2^{\mathrm{a}} \pm 1.6$} \\
\hline Lead & \multicolumn{3}{|c|}{$3.95^{\mathrm{a}} \pm 0.68$} & \multicolumn{2}{|c|}{$7.55^{\mathrm{b}} \pm 0.92$} \\
\hline Nickel & \multicolumn{3}{|c|}{$5.68^{a} \pm 1.67$} & \multicolumn{2}{|c|}{$3.84^{a} \pm 0.87$} \\
\hline Cobalt & \multicolumn{3}{|c|}{$2.67^{\mathrm{a}} \pm 0.11$} & \multicolumn{2}{|c|}{$2.96^{\mathrm{a}} \pm 0,19$} \\
\hline
\end{tabular}

by plants is facilitated by low soil $\mathrm{pH}$ levels. The acidifying action of municipal sewage sludge was reflected by lowering the content of soluble zinc in upperlays III, IV and V to the level of approx. $30 \%$ of the overall content. Given the criteria for soil, the soluble zinc content in upperlays was found to be high - above $20.5 \mathrm{mg} \mathrm{Zn} \mathrm{kg}{ }^{-1}$ (Table 2). A different relationship was identified with respect to zinc abundance in underlays (Table 3 and 4). Owing to the alkaline $\mathrm{pH}$ of the underlays, the average amount of soluble zinc was below $20.5 \mathrm{mg} \mathrm{Zn} \mathrm{kg}^{-1}$ [DIN-R-04016:1992]. The reclaimed area was characterised by the maximum overall zinc content in upperlays and underlays of 101.0 and $131.6 \mathrm{mg} \mathrm{Zn} \mathrm{kg}^{-1}$ respectively, i.e. below the admissible values as specified in the Regulation of the Minister of the Environment of 1 September 2016 on the method of conducting the assessment of land surface contamination [Journal of Laws of 2016, item 1395].

Copper is present in soil in numerous forms, generally forming not very mobile combinations with organic matter or combinations with clay minerals [Renoux et al. 2007]. The solubility of copper increases dramatically at pH 5.5 [Wuana and Okieimen 2011]. The results obtained in the present reclamation project confirm the relationship between the availability of copper for plants with an increase in substrate acidity. In upperlays III, IV and $\mathrm{V}$, there was a decrease in the soluble copper content, most likely owing to absorption by grass (Table 2). With respect to underlays, the analogous correlation was not identified. According to the applicable standards, the content of copper soluble in $1 \mathrm{M} \mathrm{HCl}$, both in underlays as well as in upperlays, was by far higher than the threshold value, which is $6.7 \mathrm{mg} \mathrm{Cu} \mathrm{kg}^{-1}$ [DIN-R-04017:1992]. The amount of copper in the reclaimed layers ranged from 31.5 to $64.6 \mathrm{mg} \mathrm{kg}^{-1}$ and the values were below the admissible levels for soils, as specified in the Regulation of the Minister of the Environment of 1 September 2016 on the method of conducting the assessment of land surface contamination [Journal of Laws of 2016, item 1395].

According to Kabata-Pendias [2011], the mean lead content in soil is $27.0 \mathrm{mg} \mathrm{Pb} \mathrm{kg}{ }^{-1}$. Both in upperlays and underlays, the identified content of this metal was lower and below $20.8 \mathrm{mg} \mathrm{Pb} \mathrm{kg}{ }^{-1}$ (Table 2 and 4). The identified level was also lower than the admissible lead content in soil as specified in the Regulation of the Minister of the Environment of 1 September 2016 which is $100 \mathrm{mg} \mathrm{Pb} \mathrm{kg}^{-1}$ [Journal of Laws of 2016, item 1395]. Lead is among the least mobile elements and, due to generally reduced solubility of its minerals, it undergoes sorption easily and forms sparingly soluble combinations in the form of mineral and organic compounds [Jalali and Khanlari 2006]. Following the change in the soil $\mathrm{pH}$ to acidic, mobile bicarbonate forms and organic complexes occur. The mobile forms of lead are present in acidic soils as $\mathrm{Pb}^{+2}, \mathrm{PbHCO}_{3}^{+}$and organic complexes. In alkaline soils, the predominant forms are: $\mathrm{PbOH}^{+}$and $\mathrm{PbCO}_{3}$. Similarly to copper, the acidifying effect 
Table 4. Overall metal content in underlay $\left[\mathrm{mg} \mathrm{kg}^{-1}\right]$

\begin{tabular}{|c|c|c|c|c|c|}
\hline \multirow{2}{*}{ Metal } & \multicolumn{5}{|c|}{ Underlay number } \\
\hline & I & II & III & IV & V \\
\hline Zinc & $82.3^{b} \pm 3.6$ & $114.7^{\mathrm{ab}} \pm 10.2$ & $102.9^{\mathrm{ab}} \pm 4.0$ & $117.8^{\mathrm{a}} \pm 10.2$ & $131.6^{\mathrm{a}} \pm 11.1$ \\
\hline Copper & $40.3^{b} \pm 3.3$ & $44.5^{\mathrm{b}} \pm 3.7$ & $46.0^{\mathrm{a}} \pm 3.3$ & $64.6^{\mathrm{a}} \pm 3.6$ & $55.8^{\mathrm{a}} \pm 5.4$ \\
\hline Lead & $13.9^{b} \pm 1.0$ & $20.8^{\mathrm{a}} \pm 0.9$ & $19.6^{\mathrm{a}} \pm 0.8$ & $19.4^{\mathrm{a}} \pm 1.1$ & $20.8^{\mathrm{a}} \pm 0.9$ \\
\hline Nickel & $30,5^{b} \pm 7.5$ & $51.9^{\mathrm{a}} \pm 4.5$ & $18.6^{\mathrm{c}} \pm 2.0$ & $22.0^{c} \pm 2.7$ & $54.1^{\mathrm{a}} \pm 10.5$ \\
\hline Cobalt & $9.1^{b} \pm 1.8$ & $11.0^{\mathrm{a}} \pm 0.9$ & $7.0^{c} \pm 0.9$ & $8.6^{b} \pm 0.9$ & $6.1^{c} \pm 0.4$ \\
\hline Metal & \multicolumn{2}{|c|}{ Unfertilized underlay } & \multicolumn{3}{|c|}{ Fertilized underlay } \\
\hline Zinc & \multicolumn{2}{|c|}{$105.5^{\mathrm{a}} \pm 7.5$} & \multicolumn{3}{|c|}{$114.2^{\mathrm{a}} \pm 5.6$} \\
\hline Copper & \multicolumn{2}{|c|}{$52.3^{\mathrm{a}} \pm 2.9$} & \multicolumn{3}{|c|}{$48.2^{\mathrm{a}} \pm 3.6$} \\
\hline Lead & \multicolumn{2}{|c|}{$20.0^{\mathrm{a}} \pm 1.3$} & \multicolumn{3}{|c|}{$17.8^{\mathrm{a}} \pm 1.0$} \\
\hline Nickel & \multicolumn{2}{|c|}{$34.3^{\mathrm{a}} \pm 4.5$} & \multicolumn{3}{|c|}{$36.6^{\mathrm{a}} \pm 3.5$} \\
\hline Cobalt & \multicolumn{2}{|c|}{$10.1^{\mathrm{b}} \pm 0.8$} & \multicolumn{3}{|c|}{$6.6^{a} \pm 0.4$} \\
\hline
\end{tabular}

of municipal sewage sludge was manifested by an increased lead uptake; in upperlays III, IV and V the amount of soluble lead was lower, on average $3.7 \mathrm{mg} \mathrm{Pb} \mathrm{kg}^{-1}$ (Table 2).

Nickel is an element necessary for the correct course of some physiological processes in plants. The occurrence of nickel in soil is mainly determined by its content in the parent material. This element is characterised by high mobility in the environment which is dependent on $\mathrm{pH}$ level and organic matter content. The mean nickel content in sandy soils ranges from 8 to $33 \mathrm{mg} \mathrm{Ni} \mathrm{kg}{ }^{-1}$ [Święcicki 2001]. The analysed upperlays showed a comparable amount of overall nickel. The underlays were characterised by a higher abundance reaching as much as $54.1 \mathrm{mg} \mathrm{Ni} \mathrm{kg}^{-1}$, found in underlay V. However, none of the underlays or upperlays showed values higher that the threshold values specified in the Regulation of the Minister of the Environment [Journal of Laws of 2016, item 1395]. In the upperlays and underlays, the amount of nickel soluble in $1 \mathrm{M} \mathrm{HCl}$ was $10 \%$ of the overall content (Table 2 and 3 ).

Mineral fertilization (NPK) applied in the initial stages of the reclamation experiment did not differentiate the overall underlay content of: zinc, copper, lead and nickel (Table 4).

Next to sodium, silicon, aluminium, selenium, iodine and chromium, cobalt is the element the presence of which in soil is considered favourable. The studies conducted by the Institute of Soil Science and Plant Cultivation (IUNG-PIB) under monitoring of arable soil chemistry in Poland show that the amount of cobalt is within 0.3-15.4 mg Co kg-1 [www.gios. gov.pl]. According to Greinert [2011], the values

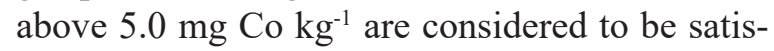
factory. The overall cobalt content in upperlays showed variability - from 7.7 to $11.4 \mathrm{mg} \mathrm{Co} \mathrm{kg}^{-1}$, and was within the range specified by IUNG-PIB for the soils in Poland. The threshold content of $20 \mathrm{mg} \mathrm{Co} \cdot \mathrm{kg}^{-1}$ in soils, as specified in the Regulation of the Minister of the Environment, was not exceeded in any of the experimental variants [Journal of Laws of 2016, item 1395]. In upperlays and underlays, the amount of cobalt soluble in $1 \mathrm{M} \mathrm{HCl}$ was at the same level $-2.5 \mathrm{mg} \mathrm{Co} \mathrm{kg}^{-1}$ (Table 2 and 3). The correlation between the decrease in cobalt solubility in soil environment, hence bioavailability, and increased $\mathrm{pH}$ was not confirmed by the results obtained in the present reclamation model. This can be explained by the fact that the observable increase in cobalt solubility occurs only in very acidic soils [Greinert 2011]. Lower amount of cobalt (6.6 mg Co $\mathrm{kg}^{-1}$ ) in the fertilized underlays, in comparison with the unfertilized underlays, can be explained by the more intense growth of the sown grass mixture and, consequently, higher cobalt intake.

\section{CONCLUSIONS}

15 years after the experiment, none of the underlays or upperlays showed an excess of threshold values as specified in the current Regulation of the Minister of the Environment of 2016. The particularly favourable effect was identified with respect to the application of fermented municipal sewage sludge and GWDA compost, which were the factors resulting in a decrease of the upperlay content of cadmium, zinc, copper and lead in the form available for plants.

Mineral fertilization (NPK) applied in the initial stages of the reclamation experiment did not differentiate the overall underlay content of: 
zinc, copper, lead and nickel. The exception was the content of cobalt in fertilized underlays. The characteristics of upperlays with respect to metal content indicate the conditions favourable to plant cultivation on the reclaimed area. The recorded results on the change of the overall and bioavailable content of metals in upperlays and underlays justify the continuation of the undertaken reclamation experiment.

\section{REFERENCES}

1. Antonkiewicz J. 2007. Effect of ash-and-sludge and ash-and-peat blends on yield of grass-birdsfoot trefoil mixture and levels of selected elements in mixture. (in Polish). Acta Scientiarum Polonorum Formatio Circumiectus, 6(3), 61-72.

2. Chaney, R.L., 2010. Cadmium and Zinc. In: Hooda P (ed) Trace elements in soils. John Wiley \& Sons, Ltd, Chichester, UK, 1-596. doi. org/10.1002/9781444319477. ch17.

3. DIN-R-04016:1992. Chemical and agricultural analysis of soil. Determination of absorbable zinc content. (in Polish).

4. DIN-R-04017:1992. Chemical and agricultural analysis of soil. Determination of absorbable copper content. (in Polish).

5. DIN-R-04021:1994. Chemical and agricultural analysis of soil. Determination of absorbable iron content. (in Polish).

6. Greinert A. 2011. Cobalt in the natural and anthropogenic environment. (in Polish). Ed. Uniwersytet Zielonogórski Zielona Góra 1-133. doi: 10.13140/2.1.2292.5764.

7. Hill T., Lewicki P. 2006. Statistics: Methods and Applications: A comprehensive reference for science, industry, and data mining. StatSoft, Inc. 832.

8. Ibragimow A., Głosińska G., Siepak M., Walna B. 2010. Preliminary study of heavy metal pollution in the floodplain sediments of the Lubusz OderGap. (in Polish). Prace i Studia Geograficzne 44, 233-247.

9. ISO 10390:2005. Soil quality - Determination of $\mathrm{pH}$. International Organization for Standardization.

10. ISO 18400-102:2017 - Soil quality - Sampling - Part 102: Selection and application of sampling techniques.

11. Jalali M., Khanlari Z.V., 2006. Mobility and Distribution of Zinc, Cadmium and Lead in Calcareous Soils Receiving Spiked Sewage Sludge. Soil \& Sediment Contamination, 15, 603-620.

12. Journal of Laws of 2016, item 1395 - Regulation of the Minister of the Environment of 1 September 2016 on the conduct of the assessment of contamination of the surface of the earth.

13. Journal of Laws of 2020, item 10 - Regulation of the Minister of Climate of 2 January 2020 on the waste catalog.
14. Kabała C., Karczewska A. 2019. Methodology of laboratory analyzes of soils and plants. (in Polish) Ed. 8a. Wrocław.

15. Kabała C., Charzyński P., Chodorowski J., Drewnik M., Glina B., Greinert A., Hulisz P., Jankowski M., Jonczak J., Łabaz B., Łachacz A., Marzec M., Mendyk Ł., Musiał P., Musielok Ł., Smreczak B., Sowiński P., Świtoniak M., UzarowiczŁ., Waroszewski J. 2019. Polish Soil Classification, 6th edition - principles, classification scheme and correlations. Soil Science Annual 70(2), 71-97. doi: 10.2478/ ssa-2019-0009.

16. Kabata-Pendias A., 2011. Trace elements in soil and plants. (Ed.), 4. CRC Press, Taylor \& Francis 280, 253-254.

17. Korzeniowska J., Stanisławska-Glubiak E., Lipiński W. 2020. New limit values of micronutrient deficiency in soil determined using $1 \mathrm{M} \mathrm{HCl} \mathrm{extractant}$ for wheat and rapeseed. Soil Science Annual 71(3), 205-214. doi.org/10.37501/soilsa/126079.

18. Lipiński W. 2013. Zasobność gleb polski w mikroelementy. (in Polish). Studia i raporty IUNG-PIB 34(8), 121-131. doi: 10.26114/sir.iung.2013.34.09.

19. Liu H., Zhao P., Qin S., Nie Z. 2018. Chemical Fractions and Availability of Zinc in Winter Wheat Soil in Response to Nitrogen and Zinc Combinations. Frontiers Plant Science 9, 1489-1515. doi:10.3389/ fpls.2018.01489.

20. Millaleo R., Reyes-Diaz M., Ivanov A.G., Mora M.L., Alberdi M. 2010. Manganese as essential and toxic element for plants: transport, accumulation and resistance mechanisms. Journal of Soil Science Plant Nutrition. 10(4), 470-481. doi.org/10.4067/ S0718-95162010000200008.

21. Parzentny H., Róg L. 2017. Evaluation of the value of some petrographic, physico-chemical and geochemical indicators, coal quality in the paralic series of the Upper Silesian Coal Basin and an attempt to find the correlation between them. (in Polish). Mineral Resources Management, 33(1), 51-76. doi 10.1515/gospo-2017-0004.

22. Renoux A.Y., Rocheleau S., Sarrazin M., Sunahara G.I., Blais J.F. 2007. Assessment of a sewage sludge treatment on cadmium, copper and zinc bioavailability in barley, ryegrass and earthworms. Environmental Pollution, 145, 41-50.

23. Siebielec G. 2012. Monitoring of the chemistry of arable soils in Poland in the years 2010-2012. (in Polish). Inspekcja Ochrony Środowiska, Warszawa $1-200$.

24. Wuana R.A., Okieimen F.E. 2011. Heavy Metals in Contaminated Soils: A Review of Sources, Chemistry, Risks and Best Available Strategies for Remediation. International Scholarly Research Notices 1- 20. doi.org/10.5402/2011/402647.

25. Yu Y., Wang Y.N., Wang Q., Li H.F. 2017. Effect of humic acid-based amendments with foliar application of $\mathrm{Zn}$ and $\mathrm{Se}$ on $\mathrm{Cd}$ accumulation in tobacco. Ecotoxicology and Environmental Safety, 138, 286-291.

26. www.gios.gov.pl/chemizm_gleb/index. php?mod=wyniki\&cz=G. dostęp 02.02.2021. 